ISMC 2021

$16^{\text {th }}$ International Strategic Management Conference

\title{
THE DIGITAL CONSUMER PROFILE IN 5.0 SOCIETS IN STRATEGIC MARKETING MANAGMENT
}

\author{
Shafag Musavi (a)*, Oqtay Quliyev (b) \\ *Corresponding author
}

(a) Azerbaijan State University of Economics, Baku, Azerbaijan, oqtay1982@gmail.com

(b) Azerbaijan State University of Economics, Baku, Azerbaijan, musavi.02.09@gmail.com,

\begin{abstract}
A digital consumer is defined as a person who can use advanced technology tools, do market research quickly through search engines, communicate with other consumers, and direct the overall process at every stage from product design to purchasing and after-sales service. Today, consumers use computer technology to make purchases and as a result, the definition of the digital consumer concept emerges. A digital consumer is a person who uses the internet to get information about a specific product they want to buy from any category or directly with a device with internet access. This article reviews research on the role of digital consumers in 5.0 societies. The purpose of this article is to explain the essence of the digital consumer concept, highlight key points about the behavior of digital consumers, and guide future research on the digital consumer. In the article, a comprehensive literature review has been made on five headings: digitalization of consumption, types of digital consumers, purchasing stages of digital consumers, factors affecting the purchasing behaviors of digital consumers. It has become clear as a result of the literature research on the digitalization of consumption and digital consumer concepts. In this research, it has been tried to create a digital consumer profile and their roles in 5.0 societies by making literature research within the scope of digital consumer types, trends they create today, purchasing stages and factors affecting purchasing behavior.
\end{abstract}

2357-1330 @ 2021 Published by European Publisher.

Keywords: Consumer behaviour, digital consumer, e-commerce, internet, 5.0 societies 


\section{Introduction}

The digital age, which entered our lives before the turn of the century, coincides with the rise of the internet and the fact that consumers are active users and at the same time maintain their vitality through social media. The increase in the use of new media as a result of the widespread use of the Internet has led to a change in consumer perception as well as the transition from traditional marketing to digital marketing.

Goodridge (2013) examines digital consumers under six headings The sixth group consists of normal digital receivers. For them, "Should I buy this product?", "Which brand should I buy?", Which products should I buy? Such questions are important and prefer digital shopping activities mainly for mobile phones or electronic products:

- The first are large digital consumers who do not have a lot of digital knowledge, but effortlessly research and buy online.

- Second, retail consumers who prefer short-term or one-off online shopping, but do not distinguish between digital shopping and traditional shopping, using it only in the context of a particular product or brand.

- Third, $72 \%$ are researchers who start out as digital consumer retail researchers to research a brand, but then continue their buying behavior with specific brands.

- Fourth are digitally motivated consumers who avoid traditional shopping as much as possible and shop using social, mobile or any digital means.

- Fifth, there are planned buyers who are very similar to consumers who are perceived as a digitally motivated slice, but have more brand choice when making purchasing decisions, and also have the idea to buy from a website where the price of the product is most affordable. or suitable.

An article by Fiore (2008) explores how the "digital consumer" can be a valuable partner for the development and production of textile and apparel products. This article highlights the importance of using digital technology in textile and apparel products to build successful partnerships. The study highlights that the use of search engines by industry experts and regular monitoring of digital consumer reviews of products or brands by websites will be valuable to the company and the consumer (Kung, 2008).

Perry et al. (2013) aimed to examine how increasing levels of object interaction on touchscreen devices have changed the need to touch digital media. This not only affects consumers' perceptions of risk when purchasing fashion products online, but also creates an interaction between consumers and online fashion products. The aim was to understand that the development of new digital technologies and computer interfaces cannot narrow the perception gap between the valuation of digital and physical products, and that this development cannot fill the tactile information gap that currently characterizes the purchase of digital fashion products. The new image interaction technology, developed using laboratorybased experimental design, was tested on a device at Shoogleit at Heriot-Watt University. The device allows users to compress, weave and digitally convert fabric patterns (Perry et al., 2013).

These findings are conferred in the context of the related literature. The study summarizes and explains the limitations of the approach and additional research areas. 


\section{Types of Digital Consumer}

While the ways digital consumers use technology are common, they are not considered a homogeneous group. Demographic variability and lifestyle set them apart from other consumer groups (Jolanta, 2016).

- Brand Advocates

- Digital Moms

- Users of the "How To" Video

- Generation Y.

Brand advocates are a digital consumer group that is open-minded, trustworthy and free to use the internet. Their strong presence on social media allows them to build a product and brand image. Consumers write openly about values, meanings and feelings through the internet and support the writing of other consumers who make important brand communication independent of the brand owner. The emergence of eWOM in this way has a wide impact on various stakeholders. Two out of three brand advocates use most of the search engines or the website of the product they are interested in when looking for information about products they want to buy (Parrott et al., 2015).

Digital moms are very knowledgeable, fashion-conscious women who are always online. They use the internet to buy more basic household items and, as a blogger, they share their online experience with their target audience. About $75 \%$ of digital moms create their content at least once a month. While searching for products, they prefer to buy products online as well as using a smart phone (Jolanta, 2016). In addition to household items, they also shop online for personal items such as clothing, shoes, and cosmetics. It is a digital consumer group who want to share their experiences with others online. This segment is ready to shop online, visit the websites of their favorite brands and look for coupons and discount products. Recent research in the literature on digital mothers recognizes the need for more research into the role of technology in the motherhood process (Treviño \& Garelli, 2019).

Users of the "How To" video are mostly consumers of video content on YouTube that shows how certain products are used, and sometimes how they can be used in a very creative and original way. Consumers and companies use such video platforms to demonstrate instructions such as cooking, sewing, mending, and cleaning. Jolanta, stated in her work, "almost 53\% of 'How To' viewers watch such videos because they want to learn something new, and the remaining $46 \%$ like to research brands they value and are happy with" (Jolanta, 2016, pp. 357-359).

Millennials or "Generation Y" were born between 1981 and 2000 and have spent most of their life online. Many millennials - those born in the early 1980s - focus on spending on emotional experiences and events rather than owning any product. They mostly use social media, but they also use the internet to search for products, shop and watch videos. Their daily life is in the form of a constant connection between two worlds, online and offline (Ram, 2017). A typical millennial's daily routine is to check the notifications on the social media platforms they use. They comment or like their friends' posts at least once a day. It is also a group of digital consumers willing to engage with close friends and sympathizers through such online platforms (Jolanta, 2016). 


\section{Buying Behavior of Digital Consumers}

One of the main reasons why digital consumer behavior is important is that important consumer information is available on the Internet. High-precision consumer data is available digitally. As a result, digital consumer behavior can be analyzed using the above data to identify consumer segments. Marketing experts have made detailed analyzes to understand the behavioral characteristics of digital consumers, and some ideas are given below (Şule, 2013).

- Digital consumers have a wealth of knowledge: Today, individuals are aware of the importance of the Internet and how they can benefit from this technology. Individuals are more aware of modern communication technologies and use them more effectively. In this context, it is necessary to inform digital consumers in detail on the Internet.

- Requires fast and relevant information: The information available on the Internet and the various options direct consumers to quick and risk-free solutions. It is very important today for any brand to use the website and social media effectively. The instant satisfaction of the consumer who visits a brand's website plays a role in motivating them to buy products and services. For this reason, when designing the websites of brands or organizations, care should be taken to ensure that they are fast, eye-catching, and as relevant as possible.

- Shareholders: Digital consumers have opportunities and platforms where they can share their experiences, send information, ask for advice, analyze, and finally comment. In this way, consumer sharing on social media plays an important role in determining their place in the digital environment (Aksoy, 2014).

\section{Identifying Digital Consumer Needs}

Consumers are aware of their needs through marketers or external exposures. Understanding the consumers' needs is the beginning of the buying process. Motivational factors can be economic, technological, psychological or personal. These are factors those marketers cannot control. But the marketer needs to watch closely for changes in these factors (Taşkın, 2005). In addition, the marketer should make an effort to mobilize the consumer with the tools at his disposal to determine the need. As with traditional markets, the use of 4P marketing can speed up the buying process by influencing the consumer himself or the environment that drives him. In addition to traditional tools, various incentive tools can be used to help consumers understand their needs digitally. These,

- Making websites easier to use

- Innovate the internal movements of the site for purchasing

- Encourage the desire to buy

- Establishing or emphasizing advisory groups (Aksoy, 2018).

\section{Digital Consumer Data Collection Phase}

After the digital consumer identifies a problem or need, they look for options and information to solve the problem as a traditional consumer. 
Consumers can easily obtain the information they want about a brand or product through the internet. Consumers actively seek information on the Internet in three different ways (Şule, 2013):

- Firstly, by browsing any site, they find the information they are looking for. While on this page, they get the information they want when they click on any of the internal or external links.

- Secondly, the user finds the desired information through a search (user browser). This method will be very convenient for the consumer if he knows the exact address of the data center.

- The third is to find the information you need by typing keywords into a search engine. Thanks to this, google.com, yahoo.com, yandex.ru and other portals are known as the most popular search engines.

\section{Evaluation of Options}

Consumers evaluate the alternatives they encounter in the purchasing decision process by comparing the features, price and quality of the product and the brand. Consumers face different types of risks associated with electronic payment methods before deciding to purchase in online markets. These (Enginkaya, 2006),

- Physical risk is the risk of bank card information being misused by others or the card being lost without permission.

- Efficiency risk- this type of risk group includes the risk that the payment will not be valid or that additional payment costs will be required.

- Financial risk- refers to financial loss online. Financial risk also includes the consumer's inability to recover the amount paid.

- Time loss risk is a risk group in which the process is not completed despite repeated payments and lost time.

Searches on some sites may provide feedback from consumers who have purchased the product before. Thus, alternative products developed are completed faster, more conveniently and on a global scale compared to traditional market conditions. Also, there are challenges faced by the digital consumer when evaluating alternatives. One of these difficulties is the constantly changing alternatives as a result of developing technologies (Şule, 2013).

\section{Purchasing Phase}

At this stage, the consumer goes to the sales point and buys the product he wants to buy. Important factors affecting the consumer's decision at the point of purchase; easy access, quality and friendly service. Purchases can be planned or unplanned, depending on the consumer. If the consumer is looking for any need, product class, product category or a particular brand, the planned purchase behavior is discussed. If a need is not identified or a purchase decision is made without the intention to purchase, it is considered impulsive buying behavior (Koç, 2016).

The above purchasing stage has some differences for the digital consumer. In the digital environment, when the consumer has no idea about what to buy, they can make a purchase decision as a 
result of an advertisement link, while doing research on any subject or browsing the internet for fun.

Digital consumers prefer to shop from sites that are simple and secure (Marangoz, 2014).

\section{Behaviors After the Purchase Stage}

In order for businesses to continue to buy from consumers, they need to continue to communicate with consumers after the purchase. This is possible by knowing whether consumers are satisfied after using the product (Noel, 2009).

The final step in the consumer decision-making process is to evaluate the performance of purchased products. There are three situations that can arise as a result of a purchase (Şule, 2013):

- In the first case, the consumer is satisfied and may be inclined to buy the product or brand again. In this case, the consumer will remain loyal to the brand.

- The second situation is that the efficiency of the product is much lower than expected, which leads to dissatisfaction among consumers. In this case, the dissatisfied consumer complains and at the same time turns to another brand without purchasing this product again. In the second case, the consumer is partially satisfied. A partially satisfied consumer conflicts with his repurchase of the product.

\section{Factors Influencing Digital Consumers' Purchasing Behaviors}

There are certain factors that shape people's needs and these factors include age, location, economic situation, social environment, occupation, counseling groups, etc. are found created accordingly. Human behavior is different from the behavior of other living things. This change is also seen in people's attitudes and behaviors towards consumption (Marangoz, 2014).

Different models have been defined to understand consumer behavior. The common denominator of these models is the grouping of factors affecting consumer behavior. Factors affecting consumer purchasing behavior are grouped under four headings (Odabaşı \& Barış, 2017).

- Demographic factors

- Socio-cultural factors

- Psychological factors

- Economic Factors.

\subsection{Demographic factors}

Demographics is an important factor in determining an individual's view of life and lifestyle. Demographic factors determine the characteristics of the consumer such as gender, age, education level, geographical location, income level and occupation (Odabaşı \& Barış, 2017).

\subsection{Socio-cultural factors}

The social environment and cultural factors that we are a part of play a very active role in defining and guiding consumer behavior. The environment in which the consumer enters creates socio-cultural 
elements. Reference groups, family, social class, culture and personal influences are called socio-cultural elements (Odabaşı \& Barış, 2017).

\subsection{Psychological factors}

Psychological factors are examined under the headings of perception, learning, motivation and attitude. Perception is the selection, arrangement and interpretation of sensations and stimuli such as sight, sound and smell. Incentives are usually automatically accepted based on experience and expectations.

The concept of learning can be defined as a continuous change in behavior. Information obtained as a result of learning is stored in memory (coding), this information is stored in memory and recalled if necessary.

Motivation is the force that pushes individuals in a particular direction to produce behavioral actions. The most famous of the motivation-based theories is Abraham Maslow's Hierarchy of Needs. Physiological needs that form the basis of this hierarchy are followed by needs for safety, love/belonging, esteem and self-actualization (Odabaşı \& Barış, 2017).

\subsection{Economic Factors}

Per capital income, which is accepted as the average income of individuals in a country, is an important criterion affecting consumption. In order to understand consumer behavior, it is necessary to look at income distribution as well as per capita income. When determining the structure of demand in a country, the behavior of consumers becomes clearer when viewed together with the figures on per capita income distribution. Although their incomes are the same, not all consumers use their income in the same way. While consumers direct their income in line with their wishes and needs, they make their decisions under the influence of many factors such as cultural factors and future expectations.

Before purchasing a product, consumers make a decision based on their economic situation, lifestyle, whether the product is suitable for their personalities or occupational groups (Odabaşı \& Barış, 2017).

\section{Other Factors Affecting Digital Consumers' Purchasing Behaviors}

In addition to factors in traditional markets, consumer behavior of digital consumers may differ from the effects of a business's online experience. In digital markets, in order to reach consumers, it is important for marketers to consider their online applications in addition to traditional marketing tools. The concept of online experience also includes marketing components that can make a difference in the web environment. For example, instant reviews, banners, emails, online submissions, and other tools are concepts that define a business' digital experience (Constantinides, 2004).

- Functional Factors. Factors that enhance the online experience by providing a virtual client with a comfortable, easy to explore, fast, interactive website. Functionality includes "usability" and "interaction". This factor is very important for the success of the electronic company in the digital environment. 
- Psychological factors. Psychological factors are those that help alleviate fraud fears and doubts about the reliability of the Website by digital customers who do not know the seller personally and are not familiar with online transactions.

- Content Factors. These are factors that refer to the creative and marketing elements of a website. These factors have a direct and decisive impact on the digital experience. It is divided into two subcategories, "Aesthetics" and "Marketing components".

\section{Conclusion and Discussion}

Today, the concept of e-commerce is highly developed and the growth in transaction volume attracts the attention of researchers. Therefore, his research has also focused on this aspect. Over time, these researches will gain more momentum and will spread to all areas of our day. In the research, individuals who regularly shop online are called digital consumers.

As a result of the literature review, we observed four types of digital consumer groups: brand advocates, digital moms, how-to video users, generation $\mathrm{Y}$.

The first group, known as Brand Advocates, is a group of consumers very enthusiastic about writing about brands. Members of this group are also commonly known as trendsetters. In addition to these features, they are eager to meet new products and spend time searching for information about products they want to buy or have bought before.

Digital moms are very knowledgeable, fashion-conscious women who are always online. In addition to household items, they also shop online for personal items such as clothing, shoes, and cosmetics. It is a group of digital consumers who want to share their experiences with others online.

Users of the "How To" video are mostly consumers of video content on YouTube that shows how certain products are used and sometimes how they can be used in a very creative and original way.

The latest digital consumer group, which is considered to be the group most interested in using mobile technologies, is the Y generation. They mostly use social media, but they also use the Internet to search for products, shop and watch videos.

Features such as rich knowledge of digital consumers, their need for fast and relevant information, and their constant sharing have also affected their purchasing behavior. Factors such as money, time and needs in the purchasing process of individuals are also important factors in shaping consumer behavior.

In the research, different models were examined in order to understand digital consumer behavior. The common point of these models is the grouping of factors that affect consumer behavior. Demographic, social, economic, cultural, psychological and other individual factors that are beyond the influence or control of marketers also affect consumer behavior or purchasing decisions.

We plan to continue this research for the Azerbaijan market in the future. In this context, we have come to the conclusion that there is not enough research in Azerbaijan. We are also planning to conduct qualitative research in this area. 


\section{References}

Aksoy, A. D. (2014). Tüketimin dijitalleşmesi [Digitization of consumption]. In M. Babaoğul, A. Şener, \& E. B. Buğday (Eds.), Hacettepe Üniversitesi Tüketici-Pazar-Araştırma-Danışma Test ve Eğitim Merkezi Tüketici Yazıları IV (pp. 46-64). TÜPADEM7.

Aksoy, R. (2018). E-pazarlama [E-marketing]. (4 $4^{\text {th }}$ ed.). Seçkin yayıncılık.

Başar, E. E., \& Durmaz, A. (2018). İnovasyon: Ekonomik ve Sosyal Eğilimler [Innovation: Economic and Social Trends]. İmaj Yayınevi.

Constantinides, E. (2004). Influencing The Online Consumer's Behavior: The Web Experience. Internet Research, 14, 111-126. https://doi.org/10.1108/10662240410530835

Enginkaya, E. (2006). Elektronik Perakendecilik Elektronik Alişveriş. Ege Academic Review, 6(1), 10-16.

Fiore, A. M. (2008). The digital consumer: Valuable partner for product development and production. Clothing and Textiles Research Journal, 26(2), 177-190. https://doi.org/10.1177/0887302X07306848

Goodridge, T. (2013). The 6 Types of Digital Consumers and Their Paths to Purchase. Compete Pulse Consumer Insights for Digital Marketers Milward Brown Digital.

Jolanta, T. (2016). Digital Consumer: Trends and Challenges. Kozminski University.

Koç, E. (2016). Tüketici Davranışı ve Pazarlama Stratejileri [Consumer Behavior and Marketing Strategies]. ( $7^{\text {th }}$ ed.). Seçkin Yayıncılık.

Kung, L. (2008). Strategic management in the media: Theory to practice. Sage. https://doi.org/10.4135/9781446280003

Marangoz, M. (2014). Internette Pazarlama [Internet Marketing]. Beta Yayınları.

Noel, H. (2009). Basic Marketing: Consumer Behaviour ( $1^{\text {st }}$ ed.). Ava Publishing.

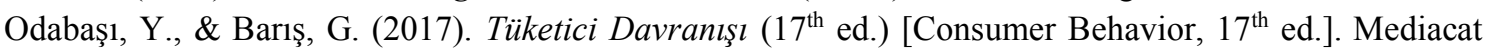
Yayınları.

Parrott, G., Danbury, A., \& Kanthavanich, P. (2015). Online behaviour of luxury fashion brand advocates. Journal of Fashion Marketing and Management: An International Journal, 19(4), 360383. https://doi.org/10.1108/JFMM-09-2014-0069

Perry, P., Blazquez, M., \& Padilla, S. (2013, September). Translating the need for touch to online fashion shopping via digital technology. In Proceedings of The First International Conference on Digital Technologies for the Textile Industries (pp. 1-11). http://www.macs.hw.ac.uk/texturelab/files/ publications/papers/Papers_PDF/Perry_Digital_Tech_for_Textiles.pdf

Ram, S. (2017, January 20). Meeting millennials where they shop: Shaping the future of shopping malls. www.mckinsey.com

Şule, Ö. (2013). A $\breve{g}$ Ekonomisinde Yeni Ticaret Yol E-Ticaret [New Trade Way E-Commerce in Network Economy]. İstanbul Bilgi Universitesi Yayınları.

Taşkın, G. (2005). Elektronik Ticaret [e-Trade]. Çizgi Ş. Kabakçı Yayınları.

Treviño, T., \& Garelli, J. L. P. (2019). Understanding digital moms: motivations to interact with brands on social networking sites. Qualitative Market Research: An International Journal, 22(1), 70-87. https://doi.org/10.1108/QMR-01-2017-0013 